University for Business and Technology in Kosovo

UBT Knowledge Center

UBT International Conference

2012 UBT International Conference

Nov 2nd, 9:00 AM - Nov 3rd, 5:00 PM

\title{
An Approach for Integration of Sustainable Transport Planning Indicators
}

Ylber Limani

University for Business and Technology, ylber.limani@ubt-uni.net

Binak Beqaj

University for Business and Technology, binak.beqaj@ubt-uni.net

Follow this and additional works at: https://knowledgecenter.ubt-uni.net/conference

Part of the Architecture Commons

\section{Recommended Citation}

Limani, Ylber and Beqaj, Binak, "An Approach for Integration of Sustainable Transport Planning Indicators" (2012). UBT International Conference. 14.

https://knowledgecenter.ubt-uni.net/conference/2012/all-events/14

This Event is brought to you for free and open access by the Publication and Journals at UBT Knowledge Center. It has been accepted for inclusion in UBT International Conference by an authorized administrator of UBT Knowledge Center. For more information, please contact knowledge.center@ubt-uni.net. 


\title{
An Approach for Integration of Sustainable Transport Planning Indicators
}

\author{
Ylber Limani, Binak Beqaj \\ University for Business and Technology \\ Prishtina
}

\begin{abstract}
This paper describes the factors that need to be considered when selecting indicators for sustainable transport planning, principles for selecting indicators, and represents an indicator integration methodology. Indicators are very important components for various assessments due to proper decision making, and the end results depend on the accuracy of selecting, integrating and measuring them. The sensitivity ratio between decision makers and planners concerning sustainable transport planning indicators selection and application is not at a desired level and it needs to be improved. This may be as a result of lack of sufficient methodologies for making indicators more practical and understandable from all engaged groups and individuals in transport planning. From this perspective this paper addresses the need for making indicators more understandable and easier to be measured for decision makers, planners and other engaged groups in transport planning. Based on the addressed needs this paper focuses on the differentiation and disintegration of indicators into more functional and easier to be measured indicators. For this purposes this paper proposes an expressive methodology for integration of sustainable transport planning indicators. The empirical evidence has shown the existence of a great number of departments, institutions and agencies carrying out research in the field of transport planning indicators. However there is a lack of appropriate and comprehensive methodology for integration of indicators. In order to assist filling this gap this paper proposes a straightforward methodology which is supposed to provide decision makers and planners with a perceptual tool for proper integration and measurement of sustainable transport planning indicators for use in specific circumstances.
\end{abstract}

Key words: sustainable transport planning, impacts, factors, indicators, integration.

\section{Introduction}

Indicators in general are selected and defined variables aimed to describe and to measure physical developments towards various objectives and other changes in time and space. Selecting and using right indicators is essential undertaking for proper analyses of trends, impacts and reflections. The impacts of an observed is sue on other is sues need to be systematically tracked. Such operations feasibly are carried out through indicators.

Despite of the widespread adoption of many approaches concerning factors and indicators in transport planning and the impact of transport on the environmental, economic and social systems, there is a deficiency of comprehensive integration and evaluation approaches to help decision-makers and planners in solving dilemmas concerning sensible trans port planning issues. Hence, in this paper in the frame of the integration of indicators, two approaches have been developed i.e. the approaches for indicator dis aggregation and differentiation. The two proposed approaches have been used to develop a combined approach for indicator integration in terms of transport. This development represents the main objective of this paper.

The research methodology has been based in a combined hypothetical and empirical approach consisting following three sub-objectives:

- This paper initially describes the indicator essentials with the reference to the concept of sustainable transport planning.

- Subsequently, the second objective of this research work is to discuss the relationship between decisive factors and specific indicators in sustainable transport planning.

- Finally the third objective of this paper represents a concept for building preconditions for the development of an approach for integration (organisation and disaggregation) of specific indicators in transport planning.

The findings and suggestions of this research work are aimed to serve decision-makers and planners as a perceptual tool proficient to contribute to the construction of stronger insight towards the achievement of sustainable transport 
planning objectives. The classification and integration approach of sustainable indicators reflect s the bases of the sustainability concept of transport planning and supports proactive planning methods where planning behaviour is tending to initiate changes rather than responding to the events.

\section{Definitions and principles for selecting sustainable transport planning indicators}

The main factors in sustainable transport planning are based on the triple-bottom line of the concept for sustainable development. This concept has been systematically developed since it was presented for the first time in the Brundtland report (UN, 1987). Sustainable trans port planning can be defined as planning that considers all factors, indicators and impacts, and the interactions between them, including those in time and space projected. In consistency with the definition for sustainable transport planning and this paper reviews and discusses the possibilities for functional integration of sustainable transport indicators which indicates the change, state of the art, activities and future perception related to main factors. Following indicator related is sues have been reviewed: definition, selection, and integration (organisation, differentiation and disaggregation).

Transport impacts the society, the economy and the environment in different ways. The assumption is that the transport impacts should be more effectively tracked through indicators. Therefore it is needed to explain more rationally the relationship between impacts of transport, causes of impacts, effects of impacts, benefits and the consequences of effects. In many literatures the terms impact and effect coincide each other. To explain evidently the situations and to avoid confusion about the terms impact and effect in transport planning, this paper assumes the following definitions:

\section{Box 1}

Specific main definitions

Baseline (orbenchmark) - existing, projected or reference conditions if change is not implemented.

Goal - what you ultimately want to achieve.

Index - a group of indicators aggregated into a single value.

Indicator - a variable selected and defined to measure progress toward an objective.

Indicatordata - values used in indicators.

Indicator framework - conceptual structure linking indicators to a theory, purpose or planning process.

Indicator set - a group of indicators selected to measure comprehensive progress toward goals.

Indicator system - a process for defining indicators, collecting and analysing data and applying results.

Indicator type - nature of data used by indicator (qualitative or quantitative, absolute or relative).

Objective - a desirable change defined in a planning process, often intended to address a problem.

Target - a specified, realistic, measurable objective.

Impact-interference or collision between two or more subjects.

Effect- a product or result produced from an impact.

Performance indicators-the measurement pointers of performance.

Performance- progress towards the achievement of goals and objectives.

Source: Adapted from Gudmundsson, 2001

Impact refers to the interference or the collision between two or more subjects (e.g. transport impact on the economy) and is assumed to be the cause or generator of effects.

Transport impacts can be intended or unintended, major or minor (complex or single), direct or indirect (Rodrigue, et.al. 2009), simultaneous and cumulative (Litman, 2011a). Nevertheless, it is important to understand the importance of main transport planning factors and their common interactions. Table 3 shows the main factors (issues impacted from transport) in transport planning and related indicators. This structure of factors may not be comprehensive as there may be otherissues included e.g. financial issues, business and technology, urban 
development, etc. Taking into consideration these is sues are not in the scope of this paper, five previously identified factors are further considered.

Effect refers to the product or result produced by impact of one is sue on another. The effect can be beneficial or consequential (positive or negative). The effects can be specified through indicators, which usually are meas urable variables (Box 1). However, not all effects may be indicated by a measurable indicator, e.g. when the impact of transport on the society have to be considered, it may be not always easy to select the best indicators which should provide with the best information about the magnitude and value of related effects.

In the Box 1 the main definitions related to indicator subject have been presented (Gudmundsson, 2001). In addition, this paper recognises the need for inclusion of the terms: impact, effect, performance indicators and performance in order to create more comprehensive subject related latitude.

Regardless of the existence and sensational activity of a great number of independent agencies, governmental organis ations and particular authors providing huge data sets concerning transport planning and transport related subjects in various countries around the world, there is no standardised method for selection and utilisation of indicators at the regional or international level. The research encompasses many of such organizations and researchers, among others: EU Statistical Bureau (EUROSTAT), European Environmental Agency (EEA), International Transport Forum (ITF), Organisation for Economic Cooperation and Development (OECD), International Monetary Fund (IMF), Victoria Transport policy Institute (VTPI), Directorate-general Energy and Transport - European Commission, United States Department for transport (U.S.DOT), transport research Board (TRB) etc.

Table 1: Possible considerations of indicators

\begin{tabular}{|l|l|}
\hline Indicators & Possible considerations \\
\hline Feasibility, liability, stakeholder`s opinion & Technical aspects of planning \\
\hline The quality of planning, costs, performance & Decision making proces s \\
\hline Travel patterns, uncertainties, restrains & Responses \\
\hline Emissions and accident rates & Physical impacts \\
\hline Injuries, deaths, ecological damages & Impacts on people and the environment \\
\hline $\begin{array}{l}\text { Cost to society due to crashes, time wastefulnes s } \\
\text { (congestion,) and environmental degradation }\end{array}$ & Economic impacts \\
\hline Accessibility, inclusion, equity & Social impacts \\
\hline Performance, mode split, speed, & Various transport trends \\
\hline
\end{tabular}

Source: Adapted from Litman 2011b, TRB 2008

As a consequence, many countries develop transport planning indicator framework depending on their mobility needs and their specific concerns. Table 1 dis plays several indicators and their possible considerations. Indicators may reflect technical planning aspects, decision making process, reactions, and physical impacts of transport on people and the environment (negative effects), economic impacts (positive en negative effects), social positive effects, trends in transport, etc. (Litman, 2011b). The selected indicators should correspondingly be capable to support various transport systemelements, e.g. trans port mode, location, time period and the evaluation of trip propose (TRB, 2008).

Based on above findings this paper proposes a different approach for addressing the sustainable transport planning indicators with reference to associated factors through following conclusions:

a. The possibility for occurrence of negative effects should be as much as possible prevented, maximally mitigated or eliminated when possible, while positive effects should be continuously maintained and improved. It would be paradoxical to as sume that a negative effect should be improved.

b. There are issues that do not easily fit within any assessment method because of their highly complex nature, their intangibility, and their immeasurability. For example affordability, equity, and fatalities and injuries from accidents represent the issues that are difficult to be measured by any proposed assessment method or by any existing measuring system.

c. The principles for selecting indicators should reflect accurately the related factors, otherwise the risk of overlapping, double counting, miscalculating, and misjudging may occur.

d. Identifying the circumstance showing that many indicator assessment approaches are in the pioneering stage, the indicator integration method is needed to assist the development of more comprehensive and rational approaches in this concern.

The principles for selecting indicators have been based on five identified decisive factors in transport planning and their reciprocal impacts. Although, five decisive factors (economic, social, environmental, land use, and 
governmental) are beyond the scope of this paper, the associated main indicators and the principles for selecting them have been further evaluated.

The process of developing indicator includes the summary of data selection standards, procedures and pract ices of strategic as ses sments.

Table 2: Principles for selecting indicators based on based practices

\begin{tabular}{|c|c|c|}
\hline Principles & Rating $^{79}$ & Interpretations $^{80}$ \\
\hline Comprehensiveness & 9 & $\begin{array}{l}\text { To reflect various economic, social and } \\
\text { environmental impacts, and various transport } \\
\text { activities (such as both passenger and goods } \\
\text { transport). }\end{array}$ \\
\hline Data quality & 9 & $\begin{array}{l}\text { To reflect high standards and to insure that } \\
\text { information is accurate and consistent (stable data } \\
\text { collection practices and providers). }\end{array}$ \\
\hline Simplicity and reliance & 8 & $\begin{array}{l}\text { To present something that people can understand, } \\
\text { believe and use (easy to interpret, showing trends } \\
\text { over time against baseline or reference values) }\end{array}$ \\
\hline Ability and clarity & 8 & $\begin{array}{l}\text { To be able to address a need (i.e. to be established } \\
\text { through stakeholder dialogue or respond to a } \\
\text { predicted significant impact), and to be analytically } \\
\text { sound }\end{array}$ \\
\hline Sensitivity & 7 & $\begin{array}{l}\text { To be sensitive to anthropogenic impacts and to } \\
\text { measure changes caused specifically by humans (i.e. } \\
\text { able to differentiate between long-term background } \\
\text { changes and those changes arising from the present } \\
\text { operations) }\end{array}$ \\
\hline Dynamic and responsive & 6 & $\begin{array}{l}\text { To response dynamically to ongoing changes in the } \\
\text { economy, society and in the environment (changes } \\
\text { over time and space) }\end{array}$ \\
\hline Easticity & 5 & To be able to address positive and negative changes \\
\hline Spatial and time relevancy & 4 & $\begin{array}{l}\text { To be applicable across the required geographical } \\
\text { level (i.e. local, regional, global), and time oriented. }\end{array}$ \\
\hline Validity and reliability & 3 & $\begin{array}{l}\text { To be valid based on the international standards and } \\
\text { reliable using technically defensible measurement } \\
\text { techniques. } \\
\text { Provide a basis for national and international } \\
\text { comparisons } \\
\text { To have a reference comparable value }\end{array}$ \\
\hline Efficiency & 2 & $\begin{array}{l}\text { To be cost-effective and involve the appropriate level } \\
\text { of effort }\end{array}$ \\
\hline Policy relevancy and user utilisation & 1 & $\begin{array}{l}\text { To be relevant to policy (easy to interpret, showing } \\
\text { trends over time against baseline or reference values) } \\
\text { and easy to be used by the user. }\end{array}$ \\
\hline
\end{tabular}

Source: Adapted from TRB 2008, Litman 2011a, Litman 2011b

In conclusion, when selecting indicators it is essential to ensure they among others are: comprehensive, represent quality data, simple and confident, clear and measurable, sensitive, dynamic and responsive, elastic, spatial and timely relevant, valid and reliable, efficient and policy relevant.

\footnotetext{
${ }^{79}$ Rating of indicat ors has been presented for recommendation purposes

${ }^{80}$ Some of these criteria describe the "ideal" indicator; not all of them will be met in the practice.
} 
The table 2 represents a rudimentary form of most relevant principles for selecting indicators. It is important to note that this is not a comprehensive criterion for indicator selection; however, these basic principles and following indicator integration approaches under the sections 4 and 5 of this paper are aimed to construct a consistent perception tool for indicator assessment which is supposed to be utilised from policy makers, planners and other engaged groups and individuals in transport planning. The selected indicators should be measurable and capable to provide with quality data useful and available to decision makers, planners and to the general public.

\section{Organising indicators}

Depending on their indication strength and transport impact implication, indicators may be organised as a single indicator or as a set of indicators. Indicator sets are composed from indicators from each of the factors involved in the observed and analysed situation, e.g. when observing the transport infrastructure improvement projects, lack of links possibly will have multiple impacts such as economic, social and environmental.

These impacts occur at the same time and at the same location producing negative or positive effects.

Table 3: The structure of transport planning indicators with respect to main factors

\begin{tabular}{|c|c|c|}
\hline \multirow{2}{*}{$\begin{array}{l}\text { Sustainability factors } \\
\text { (categories) }\end{array}$} & \multicolumn{2}{|c|}{ Indicators (sub-categories) } \\
\hline & Most important & Supportive \\
\hline Economic & $\begin{array}{l}\text { Economic development } \\
\text { Economic efficiency } \\
\text { Mobility } \\
\text { Congestion } \\
\text { Productivity }\end{array}$ & $\begin{array}{l}\text { Pricing } \\
\text { Regional cohesion } \\
\text { Competitiveness } \\
\text { Economic costs of crashes (accidents) }\end{array}$ \\
\hline Environmental & $\begin{array}{l}\text { Air quality } \\
\text { Energy use } \\
\text { Noise } \\
\text { Climate change } \\
\end{array}$ & $\begin{array}{l}\text { Spatial quality } \\
\text { Biodiversity } \\
\text { Waste } \\
\text { Natural resources depletion } \\
\end{array}$ \\
\hline Social & $\begin{array}{l}\text { Acces sibility } \\
\text { Equity } \\
\text { Safety and security } \\
\text { Community cohesion }\end{array}$ & $\begin{array}{l}\text { Welfare } \\
\text { Health } \\
\text { Cultural heritage preservation } \\
\text { Accessibility } \\
\text { Noise } \\
\text { Affordability }\end{array}$ \\
\hline Land use & $\begin{array}{l}\text { Urban sprawl } \\
\text { Transport land consumption } \\
\text { Accessibility decrease } \\
\text { Car dependency }\end{array}$ & $\begin{array}{l}\text { Mobility increase } \\
\text { Low density housing (sub-urbanization) } \\
\text { Increased urban population and rapid } \\
\text { urbanization } \\
\text { Land uses separation (zoning) } \\
\text { Change of the life style } \\
\text { Creation of megacities }\end{array}$ \\
\hline Good governance & $\begin{array}{l}\text { Open and cooperative policy } \\
\text { Integrated comprehensive and inclusive } \\
\text { planning (sustainable transport } \\
\text { planning) } \\
\text { Democratic legitimacy and integral } \\
\text { efficiency }\end{array}$ & $\begin{array}{l}\text { Demand management and network } \\
\text { management } \\
\text { Uncertainty and constrains management } \\
\text { Optimal technology and innovation } \\
\text { development }\end{array}$ \\
\hline
\end{tabular}

Source: Adapted from Litman 2009, TRB 2008, Gudmundsson, 2001

The produced effects may be measured by the means of relevant indicators. Consequently, they can be compared with the performance indicators that reflect the impact of infrastructure improvement as a measure to mitigate the impacts of link deficiency. Table 3 shows the primary relationship of factors obvious in the most of recent transport planning models (sustainability factors), and supplementary factors that intensely vary depending on the installed political systemof a specific country or region.

Table 4: The structure of unsustainable and sustainable transport planning indicators with respect to main factors 


\begin{tabular}{|c|c|c|}
\hline \multirow[t]{2}{*}{ Sustainability factors } & \multicolumn{2}{|c|}{ Indicators } \\
\hline & Uns us tainable & Sustainable \\
\hline Economic & $\begin{array}{l}\text { Congestion, crowding } \\
\text { Traffic fatalities and injuries } \\
\text { Inequity } \\
\text { Economic costs of crashes (accidents) }\end{array}$ & $\begin{array}{l}\text { Economic development } \\
\text { Economic efficiency } \\
\text { Mobility } \\
\text { Productivity } \\
\text { Regional cohesion } \\
\text { Competitiveness }\end{array}$ \\
\hline Environmental & $\begin{array}{l}\text { Air pollution } \\
\text { Energy use } \\
\text { Noise } \\
\text { Climate change } \\
\text { Biodiversity distraction } \\
\text { Spatial quality reduction } \\
\text { Waste } \\
\text { Natural resources depletion }\end{array}$ & $\begin{array}{l}\text { Air quality improvement } \\
\text { Emission reduction } \\
\text { Energy use reduction } \\
\text { Clean and renewable energy resources } \\
\text { development } \\
\text { Preservation of spatial quality } \\
\text { Waste recycling } \\
\text { Eco efficiency } \\
\text { Noise mitigation }\end{array}$ \\
\hline Social & $\begin{array}{l}\text { Noise pollution } \\
\text { Accidents } \\
\text { Congestion } \\
\text { Health damage } \\
\text { Noise } \\
\text { Cultural heritage destruction } \\
\text { Social exclusion }\end{array}$ & $\begin{array}{l}\text { Accessibility } \\
\text { Mobility } \\
\text { Equity (infrastructure and transport } \\
\text { resources improvement and equivalent } \\
\text { prizing) } \\
\text { Cultural heritage preservation } \\
\text { Welfare } \\
\text { Affordability } \\
\text { Community cohesion }\end{array}$ \\
\hline Land use & $\begin{array}{l}\text { Urban sprawl } \\
\text { Car dependency } \\
\text { Land take } \\
\text { Mobility increase } \\
\text { Low density housing (sub- } \\
\text { urbanisation) } \\
\text { Increased urban population and rapid } \\
\text { urbanisation } \\
\text { Land fragmentation }\end{array}$ & $\begin{array}{l}\text { Smart growth, } \\
\text { Human behaviourchange rate } \\
\text { Territorial cohesion } \\
\text { Touristic development } \\
\text { Rural areas connection-inclusion }\end{array}$ \\
\hline Governance & $\begin{array}{l}\text { Insufficient expertise and knowledge } \\
\text { Reactive planning behaviour } \\
\text { Obscure policy } \\
\text { Negligence } \\
\text { Unequal aspect ratio with respect to } \\
\text { technical factors (planners) } \\
\text { Conventional and reductionist } \\
\text { approach }\end{array}$ & $\begin{array}{l}\text { Open and cooperative policy } \\
\text { Integrated comprehensive and inclusive } \\
\text { planning } \\
\text { Uncertainty and constrains management } \\
\text { Optimal technology and innovation } \\
\text { development } \\
\text { Proactive planning behaviour } \\
\text { Improved aspect ratio between technical } \\
\text { and policy making factors }\end{array}$ \\
\hline
\end{tabular}

The level of recent economic development of the respected country or region plays a great role in the process of factor and indicator selection (e.g. accessibility in developed countries should not be equally understood as in the case of developing countries, since in developed countries the accessibility has reached an attitude where possibly no large development is needed).

This established practice of organising factors and related indicators as presented in the tables 3 and 4 is supported by means of the concept of sustainable transport planning. It may be assumed that not all transport related undertakings and activities produce intended impacts with positive effects, and not all transport activities are equally important. Accordingly, the indicators as sociated with factors have been organised into important (always preferable) and supportive (conditionally preferable).

The above assumption has produced preconditions for further structuring of indicators into unsustainable (presenting and measuring negative effects of transport) and sustainable indicators (desirable or required effects of transport) as displayed in the Table 4. 
Table 4 represents creative approach toward better identification and structuring of sustainable indicators through initially identification of those that are verified or assumed to be non-sustainable and these recognised and supported by the sustainable trans port planning concept.

This structural method does not represent a comprehensive or indexed form of organising factors and indicators; however, it structures conceptual factors and related indicators and shows the oppositional interpretation of various indicators.

Performance indicators basically represent the measurement pointers of performance, while performance represents progress toward the achievement of strategic goals and objectives. Performance indicators are beyond of the scope of research work; however it is important to note that there is a strong relationship between impact and the performance of transport. Therefore the recommendation can be made for more research in this area.

In conclusion indicators should be organised in order to be understandable, meaningful and measurable to decision makers, planners and other stakeholders. The decision making levels and technical factors concerning transport planning should be more cohesive in order to improve the as pect ratio between technical achievements and political visions. In this matter the proper indicator selecting procedures and principles, and the appropriate and perceptible indicator organisation scheme should reflect the policy context and should influence the corresponding level of specific issues.

\section{The methodology for indicator integration}

There is empirical evidence showing the need for integration of indicators, different interpretations concerning the importance and value of transport planning indicators. Indicators in sustainable transport planning represent variables that measure progress toward specified objectives and they take into account a wide range of transport impacts (Litman and Burwell, 2006). Indicators can reflect different levels of analysis, decision-making process, responses and physicalimpacts of various is sues.

Indicators may also reflect different technical aspects of planning, e.g. feasibility, responsibility, stakeholder's opinions, etc. (Litman, 2011a). Table 5 shows how indicators can measure various levels of impacts, from external trends through the social and environmental and economic impacts, to performance evaluation (TRB, 2008). Physical impacts of transport may be reflected through GHG emissions and accident rates, and their effects on the society and the environment, e.g. ecological damages, injuries and deaths (TRB, 2008). However, there is no structured methodology for integration of indicators for the purposes of sustainable transport planning. The methodology presented in Figure 1 has been structured being based on the cause-and-effect diagram and includes following elements:

- $\quad$ Couse factors (e.g. users, infrastructure, operations, etc.)

- $\quad$ Events (e.g. accidents, congestion, noise, etc.)

- Impacts of events (economic, environmental, social, land use, political, etc.)

- Effects of impacts (mobility increase, accessibility improvement, crash costs, land used, land fragmented, air quality deterioration etc.)

- Measurement of indicators (physical units, monetary, psychological, etc.

- Feedbacks (responses in the case of improper selected indicator, not sufficient differentiated and integrated indicator, etc.) 


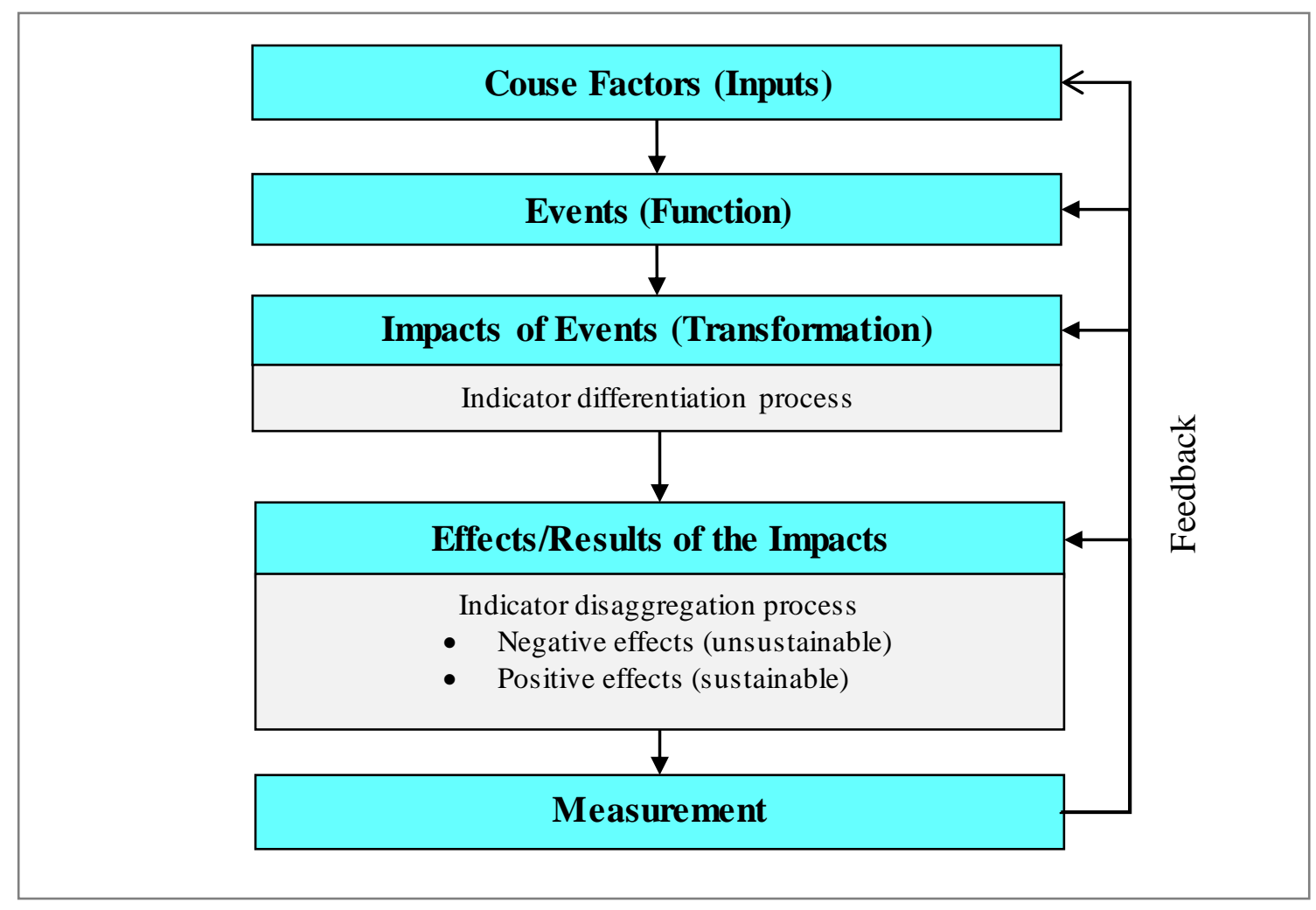

Figure 1: The rational methodology for indicator integration

It is not always simple to measure an indicator, since the situations where the measurement should be performed, and the impacts may be complex. In this case this paper identifies the need for more comprehensive indicator integration approach which should result in the increase of indicator elasticity and dynamics.

The indicators should be integrated at a level where their disaggregation and simplification should be performed without losing in weight and confidence (elasticity). Disaggregated indicators should support particular types of analyses such as demographic, geographic, and travel activity analysis, e.g. the equity analysis should compare transport quality with accessibility or mobility with transport affordability when the needs of disadvantaged groups of people should be taken into consideration (dynamics).

A particular process, change, problem or opportunity may seem needed and effective when measured in a specified way, while it may be unwanted and ineffective when measured in other way.

For example, economic productivity seems to be greatly dependent on mobility magnitude when measured from economic view, while it reflects the negative development when measured from the environmental viewpoint. For above reasons the trans port planning process requires the selection of indicators in advance which are measurable and relevant to the impact of transport on the particular issue as displayed in the tables 3 and 4.

The implementation

The Figure 3 represents possible implementation case of the rational indicator integration methodology. The signification of accident as an unsustainable indicator, the possible cause factors of accidents, the effects of accidents and the differentiation and disaggregation scheme of indicators required to measure the magnitude of the impacts and accidents. The scheme is not exhaustive, since it may contain various cause factors and impacts. However the proposed method may be implemented for integration of various indicators for the purposes of sustainable transport planning.

Since sustainable transport planning depends on data from a variety of sources to provide a complete print of the economic, environmental, and social impacts as well as the basic functionality of transport projects (FHWA, 2011), it requires exact selection of indicators. Nevertheless, selecting proper indicators is not an easy task considering that the nature of impacts is different and not always determinable. Some indicators related to more complex issues show lack of accurate data, e.g. equity, accessibility, affordability, while some other indicators are run over by data, e.g. indicators of system state, air quality, congestion, etc. (OECD, 2005). 


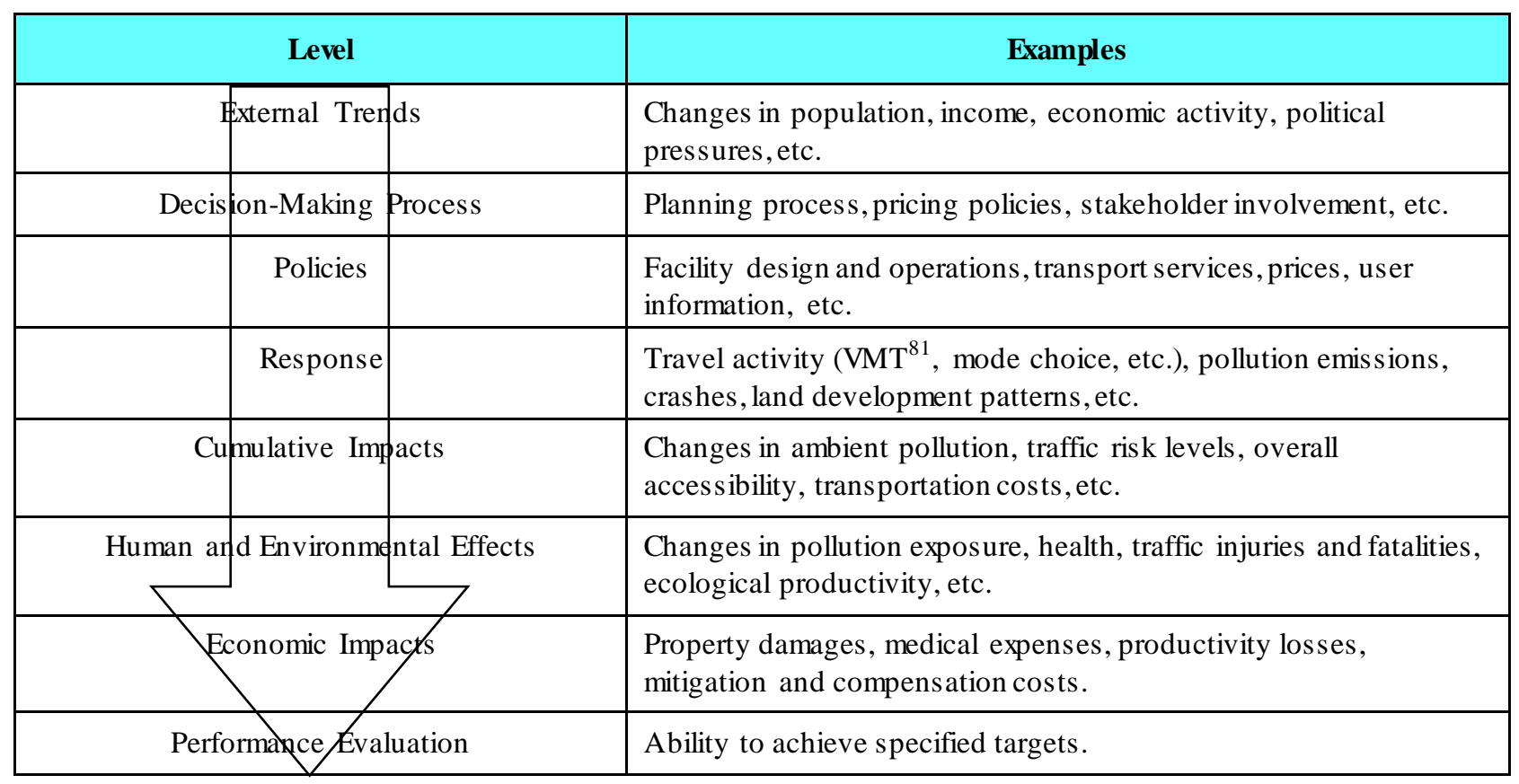

Figure 2: Measuring example of various levels of impacts

Source: TRB 2008

The Figure 2 shows the proposed structure of process levels for as sessing impacts: impact complexity level, indicator extension level, analysis of impact interferences and interaction level, indicator differentiation level, indicator measurement level and result assessment level.

Some undertakings, activities and constitutive elements of transport systemrequire simple indicator sets because their impact on related is sues is low or uncomplicated, while some other require a comprehensive indicator set or a group of sets because of their complexity and their higher impact on related issues (EEA, 2011).

Potential sustainable transport planning indicators should be built based on backward data research (transport related statistics and practices), on recent state, and on the future expectations (scenario planning) concerning transport planning developments (TRB, 2008). Backward data research should result in a clear reflection of weaknesses and strengths of transport from the past and from the present and should give the indications for possible transport developments in the future.

In conclusion indicators may be simple or complex depending on the is sues they track and measure. Above assumptions and findings supports the rationale for building the indicator integration methodology. Recog nising the context where developments in transport planning may be complex by implicating various factors, the decision making needs to be supported by more understandable and easy to use approach concerning possible impacts, effects, consequences, and benefits of transport in specific circumstances.

There are various levels of transport impacts. Figure 2 displays an example of impact levels and various related considerations. The process of indicator differentiation proposed by this integration methodology is supposed to separate the impact levels. To perform an accurate differentiation of indicators into more specialised indicators is predecessor process of indicator disaggregation into little and measurable indicators. The latest stadium of the integration process is the completing of indicator measurement.

${ }^{81}$ Vehicle-Travelled-Miles 


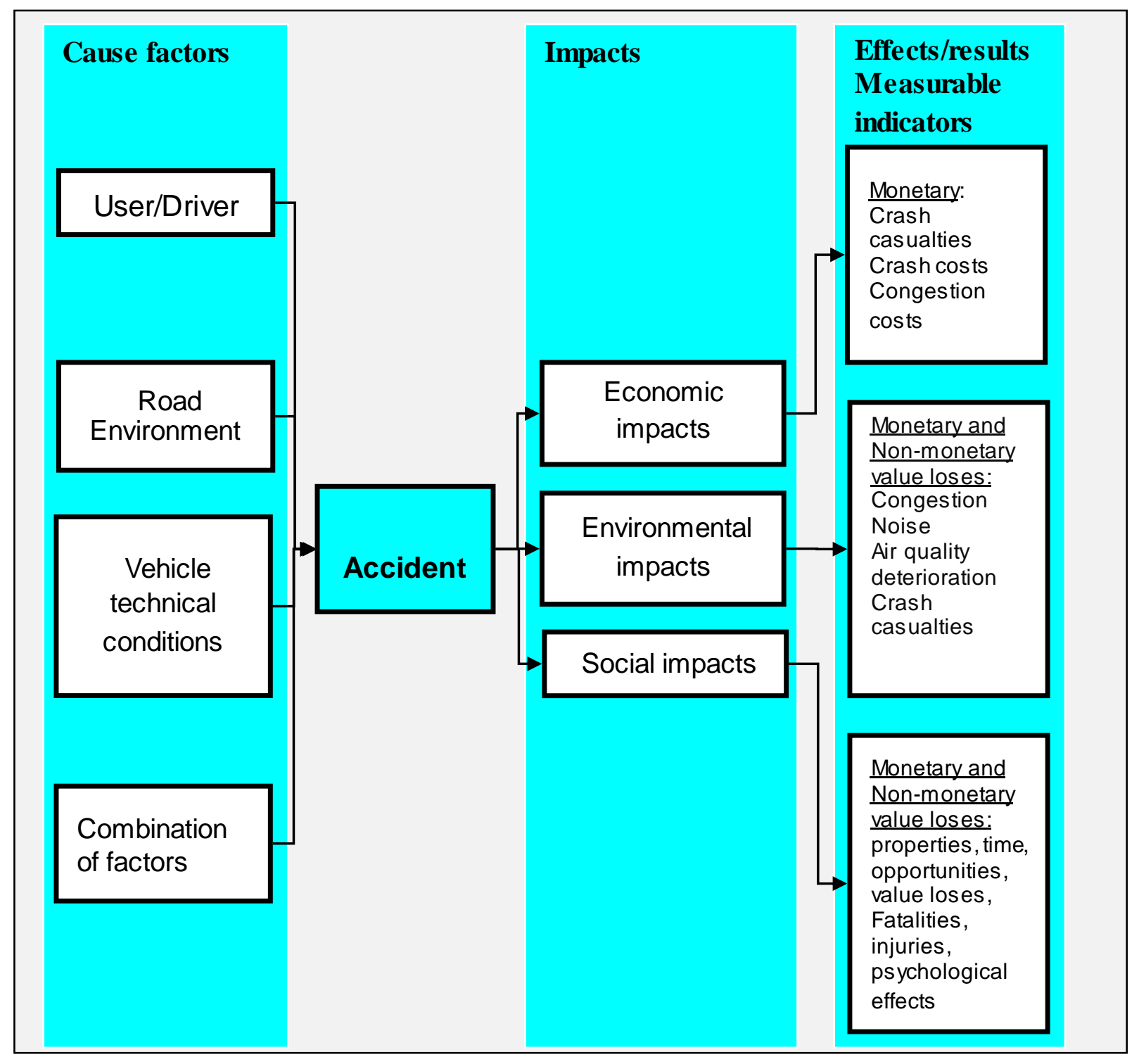

Figure 3: Proposed approach of indicator differentiation/disaggregation

Observing a single factor or a sub-factor e.g. safety and security (accident) as presented in the Figure 3; it can be assumed that it represents a reasonably difficult subject that needs to be measured. To make it less complex, the magnitude and intensity of safety and security should be indicated by simple understandable and verifiable indicator e.g. by accidents. Furthermore, this indicator stretches multiple indications and should be further disaggregated in less complex indicators such crash casualties and crash costs. When required, these indicators may be further disaggregated into smaller, easily and accurately measurable indicators. This description represents the analysis of factors and related indicators and systematic integration (differentiation and disaggregation) process regarding to their significance.

Differentiation means transforming indicator into different and more specific categories, while disaggregation is process of sorting out of indicators from a whole into constituent parts. Depending on the desired information, the combination of different indicators is possible. They can be as sessed one relative another e.g. transport demand growth may be measured relative to the GDP growth. An indicator may be disaggregated in indicators of smaller size or it may be differentiated in specific indicator groups by demographic and geographic factors (Litman, 2011b). Indicators may be differentiated and disaggregated in more specialised indicators e.g. by type, by travel conditions, by mode, by type of emissions, by user type, etc. (TRB, 2008).

Table 5: Sample of indicator disaggregation 


\begin{tabular}{|l|l|l|l|l|l|}
\hline Category & Subcategory & Indicator & $\begin{array}{l}\text { Desired } \\
\text { development }\end{array}$ & Disaggregation & Rating $^{\mathbf{2}}$ \\
\hline \multirow{5}{*}{$\begin{array}{l}\text { Safety and } \\
\text { Security } \\
\text { (Accidents) }\end{array}$} & $\begin{array}{l}\text { Crash } \\
\text { Casualties }\end{array}$ & $\begin{array}{l}\text { Crash deaths and } \\
\text { injuries }\end{array}$ & $\begin{array}{l}\text { Mitigation or } \\
\text { elimination }\end{array}$ & $\begin{array}{l}\text { Mode, road type and } \\
\text { cause of impact }\end{array}$ & 9 \\
\cline { 2 - 6 } & Crashes & Reported crashes & Mitigation & $\begin{array}{l}\text { Mode, road type and } \\
\text { cause of impact }\end{array}$ & 5 \\
\cline { 2 - 6 } & Crash costs & $\begin{array}{l}\text { Traffic crash } \\
\text { economic costs }\end{array}$ & Mitigation & $\begin{array}{l}\text { Mode, road type and } \\
\text { cause of impact }\end{array}$ & 7 \\
\cline { 2 - 6 } & $\begin{array}{l}\text { Congestion } \\
\text { costs }\end{array}$ & Time wasted & Reduction & Mode, location, time & 7 \\
\cline { 2 - 6 } & $\begin{array}{l}\text { Inefficient fuel } \\
\text { consumption }\end{array}$ & Reduction & Mode, location, time & 6 \\
\cline { 2 - 6 } & $\begin{array}{l}\text { Vehicle operation } \\
\text { costs }\end{array}$ & Reduction & Vehicle type, mode & 3 \\
\hline
\end{tabular}

Source: Adapted from: Litman 2011a

Analysing the category of safety and security from the Table 5, the differentiation and disaggregation of this indicator category produces four related indicator subcategories. New produced indicators from desegregation process may be the number of deaths and injuries, police investigation reports and economic costs of crashes. Congestion costs represent additional subcategory indicated by time wasted, inefficient fuel cons umption and vehicle operating costs. The cause of congestion in this case is the accident and the information comes directly from safety and security category. Wasted time sub-indicator is not suitable in the evaluation of the environmental impact of accident, while inefficient fuel consumption has triple indication: economic, environmental and social. Rating of indicators shown in the right side column of the Table 5 represents a recommended approach for assisting in achieving more inclusive indicator assessment methodologies (the indicator rating approach is for the same purposes as presented in the Table 2).

In conclusion the impacts of transport on five identified factors may be single, multiple, and multiple and complex depending on the situation and the magnitude of interaction and interference between factors. The efficient evaluation of multiple and complex impacts (e.g. impacts of congestion and accidents) depend on the accuracy of indicator selection, organisation, and integration. The measurement results are basis for setting correct transport planning objectives. The results accuracy influences greatly the process of problem or opportunity identification. Finally the finding of appropriate solutions to mitigate possible negative effects and to utilise the opportunities depend on the measurement correctness.

The development method of indicators and indicator sets is not in the scope of this paper. The indicator study subject is limited in the indicator selection principles which have been performed in consistency with definitions and indicator integration methodology.

Particular efforts have been made to consolidate indicator indexes which should comprise a specified number of indicators to provide with a single output value (Black, 2002). Such index may not be comprehensive since the impacts are various and measurement units and different information are difficult to be integrated. Consequently, the more information driven into a single index, the less significance and sense it has for the policy objectives (TRB, 2008).

\footnotetext{
${ }^{82}$ Proposed rating from 1 - less important to 9 -very important. Similar rating purpose has been proposed in the Table 2
} 


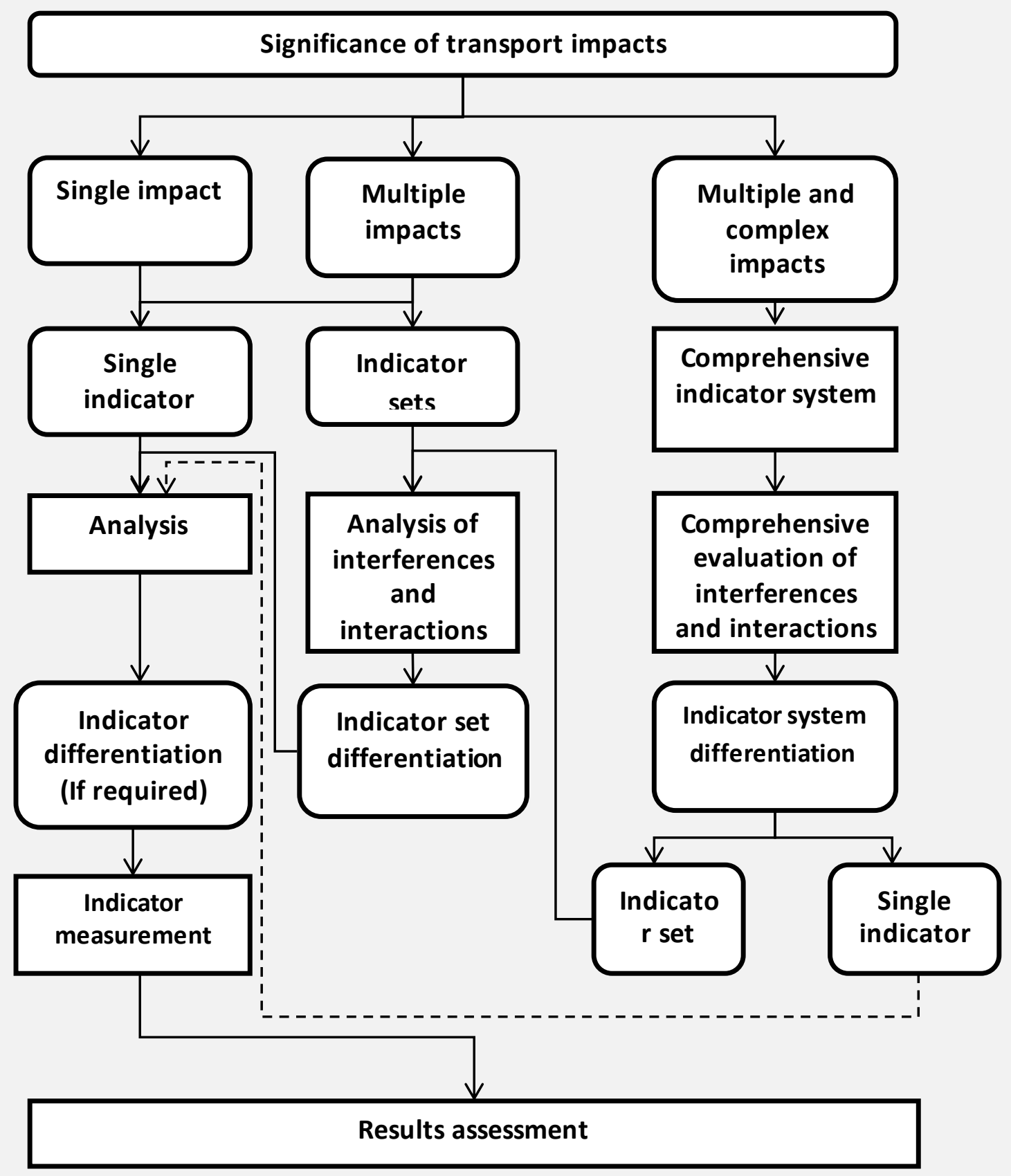

Figure 4: The proposed integrated scheme for organising, differentiating and measuring indicators in terms of transport impacts

5. Conclusions and recommendations

The rationale behind the assumptions made in this research work is coherent with following conclusions:

- The division of indicators into unsustainable and sustainable represents a step towards logical understanding of essential differences between the existing state of the transport and the outline of envisioning transport. This will help to avoid eventual recurrences, needles multiple measurements and overlapping of indicators especially in the regions in transition e.g. in the SEE region where transport planning require various implications. 
- The discussions about sustainability are mostly focused on unsustainable transport factors and indicators. Considerable research work is required to make such factors and indicators sustainable, or to take actions to mitigate their negative (unsustainable) affects. This position is uncertain considering that sustainable transport is required now and in the future.

- The reflective identification and definition of unsustainable indicators does not inevitably mean that the course of sustainability is established. However, the perspective identification and definition of sustainable transport indicators can be understood as a conceptual step towards sustainable transport planning.

- Perceptive identification of problems, needs and opportunities belong to the political activity scope, while the definition and practical governance of sustainable indicators belongs to the technical operational area.

- The proposed division strategy of indicators creates better conditions to attain an accurate image of sustainable transport planning and accentuates the efforts that should be made to achieve it. It may be very useful methodology for decision makers and planners in countries in transition such as in the case of Western Balkan.

A disadvantage of the indicator integration approach pres ented in this paper may be its excessively descriptive latitude. However, considering that the sustainable indicator as sessment approaches are in the pioneering stage, the approach provided by this paper is aimed to serve as a control tool capable of providing decision makers and planners with more perceptibility for managing and aligning sustainable transport planning indicators.

The paper concludes that negative impacts of transport may be prevented, maximally mitigated or possibly eliminated, while positive effects may be continuously maintained and improved. This process requires proper indicator selection principles, indicator integration and accurate measurement. It would be paradoxical to assume that a negative impact should be improved by any planning approach.

Reference list

1. UN (1987). Development and International Economic Cooperation: Environment. Report of the World Commission on Environment and Development. UN General Assembly A/43/427 Original Report

2. Rodrigue, J-P., Comtois, C., Slack, B. (2009). The Geography of Transport Systems. Routledge, New York.

3. Litman T. (2011a). Well Measured Developing Indicators for Sustainable and Liveable Transport Planning. Victoria Transport Policy Institute [online]. Available at: http://www.vtpi.org/wellmeas.pdf

4. Litman, T. (2011g). Developing Indicators for Comprehensive and Sustainable Transport Planning [online]. Available at: http://www.vtpi.org/sus_tran_ind.pdf

5. Gudmundsson, H. (2001). Indicators and Performance Measures for Transportation, Environment and Sustainability in North America, National Environmental Research Institute, Research Notes No. 148 Ministry of Environment and Energy, National Environmental Research Institute, Denmark

6. TRB (2008). Sustainable Transportation Indicators Subcommittee ofthe Transportation Research Board (ADD40 [1]).Paper 09-3403, 2009 Transportation Research Board Annual Meeting [online]. Available at: http://www.vtpi.org/sustain/sti.pdf

7. Litman T. and Burwell, D. (2006). Is sues in Sustainable Transportation, International Journal of Global Environmental Issues, Vol.6, No. 4, pp. 331-347

8. TRB (2008). Sustainable Transportation Indicators Subcommittee of the Transportation Research Board (ADD40 [1]). Paper 09-3403, 2009 Transportation Research Board Annual Meeting [online]. Available at: http://www.vtpi.org/sustain/sti.pdf

9. FHWA (2011). Transportation Planning and Sustainability Guidebook [online]. Available at: http://ahtd.info/yahoo_site_admin/assets/docs/Trans_Planning_4_Sustain-Guidebookreduced.24985631.pdf 
10. OECD (2005). Measuring Sustainable Development. Statistics brief No 10. Statistics Directorate of the OECD, Paris.

11. EEA (2011). Laying the foundations for greener transport. TERM 2011: indicators tracking transport and environment in the European Union. European Environmental Agency, Copenhagen 